\title{
Article \\ The Interplay of Objectivity and Subjectivity in Landscape Character Assessment: Qualitative and Quantitative Approaches and Challenges
}

\author{
Theano S. Terkenli (D), Aikaterini Gkoltsiou *(D) and Dimitris Kavroudakis (D) \\ Department of Geography, University of the Aegean University Hill, Mytilene, 81100 Lesvos, Greece; \\ t.terkenli@aegean.gr (T.S.T.); dimitrisk@aegean.gr (D.K.) \\ * Correspondence: agkolj@otenet.gr
}

check for

updates

Citation: Terkenli, T.S.; Gkoltsiou, A.;

Kavroudakis, D. The Interplay of

Objectivity and Subjectivity in

Landscape Character Assessment:

Qualitative and Quantitative

Approaches and Challenges. Land

2021, 10, 53. https://doi.org/10.3390/

land 10010053

Received: 12 December 2020

Accepted: 4 January 2021

Published: 8 January 2021

Publisher's Note: MDPI stays neutral with regard to jurisdictional clai$\mathrm{ms}$ in published maps and institutional affiliations.

Copyright: $(\odot 2021$ by the authors. Licensee MDPI, Basel, Switzerland. This article is an open access article distributed under the terms and conditions of the Creative Commons Attribution (CC BY) license (https:// creativecommons.org/licenses/by/ $4.0 /)$.

\begin{abstract}
Landscape character assessment (LCA) methods have been used in the past few decades to analyze, classify, and map landscape types, using objective and subjective approaches, with the aid of both quantitative and qualitative data. This paper addresses and critically evaluates the compromises and ways in which contemporary LCA methodologies employ (or profess they employ) objective versus subjective and quantitative versus qualitative data and analytical tools, in their conceptualization and implementation. It begins with an extensive literature review of the ways in which the objective/subjective and the quantitative/qualitative variables interweave in currently practiced or proposed versions of LCA. With the aid of meta-analysis, the paper traces and discusses the recent evolution, methods, concessions, and risks of such endeavors, and develops an integrative conceptual model for critical assessment, analysis, and negotiation of the interplay between objectivesubjective and quantitative-qualitative constituent parts of existing LCA methodologies. It concludes by pointing to pitfalls and prospects, in the broader attempt towards a more concerted, integrative approach to LCA development and practice, both appropriate to its challenges and adaptable to time-space-culture-discipline landscape particularities and means of implementation.
\end{abstract}

Keywords: landscape character assessment; meta-analysis; subjective vs. objective; quantitative vs. qualitative

\section{Introduction and Study Context}

The European Landscape Convention (ELC) [1] promotes the protection, management, and planning of all landscapes; it has long been considered as our best landscape stewardship tool, at least as concerns European landscapes. One of the major principles on which ELC measures are based is the identification of landscape character, as well as the pressures and drivers of change, as regards the implementation of strategies for landscape management, planning, and protection. Such principles and strategies require a systematic knowledge of their variation, spanning the full range of spatial scales that define the landscape level, i.e., in landscape typologies. Although it is widely acknowledged that there is a lot of potential for promoting holistic landscape study and sustainability by using the guiding principles of the ELC [2], important inroads remain to be made in its practical application in landscape stewardship [3], very much due to difficulties in contextualizing landscape assessment/characterization/mapping.

Landscape character assessment (LCA), once seen as central to the implementation of the ELC [4], is now in a process of regrouping, reconsideration, and renewal, at least as concerns peripheral regions in/of Europe, trying to "catch up" with Northern and Western European regions [5-7]. As a process, LCA is mostly concerned with documenting landscape character and, as such, it is divided into two main phases. The first phase, landscape characterization, concentrates on what makes one area different from another, by 
identifying, classifying, and mapping areas of distinctive character, and results in the drafting of landscape character types and areas. In the second phase, judgements are imparted about landscape character, leading to decisions concerning the management, planning, and protection of the various landscape types/areas. Landscape character assessment thus provides an important strategic overview, on the basis of which policies are developed towards landscape multifunctionality and resolution of conflicting demands between agriculture, development, recreation, and nature conservation. Therefore, LCA is a useful tool for a variety of different sectors related to landscape planning and management, as well as for "the implementation of landscape policies, especially the integration of landscape objectives into territorial strategies, with the active cooperation and participation of all the social agents affecting a territory" [8], as regards both environmental and societal goals.

As a broadly acknowledged and established method of landscape assessment, characterization, and mapping, with the aid of both quantitative and qualitative data, LCA combines both subjectivity and objectivity—and has been practiced and employed this way in a variety of cases. As a process of characterization, it must be objective, while, as a tool informing decisions, it must lead to judgements involving an element of subjectivity. Furthermore, the LCA method relies on data of both a quantitative and qualitative nature, at least owing to the fact that the landscape, by definition, is constituted in a relational way, through human perception and interaction [1,9]. It is also broadly acknowledged that subjective judgements are involved in all decision phases concerning landscape character assessment, from surveying landscape elements to mapping and describing landscape types.

However, there is a lack of research on a critical assessment of this twofold perspective (subjective vs. objective, in conjunction with qualitative vs. quantitative) to LCA and mostly a review of relevant research capturing this aspect. This is precisely the goal of this study; namely, to review the most recent research spanning the time period of the past 20 years, addressing the problem of subjectivity and objectivity in LCA methods, and to critically assess issues of applicability and value of this method, with a view to its future uses.

This paper thus addresses and critically evaluates the compromises and ways in which contemporary landscape character assessment (LCA) methodologies employ (or profess they employ) objective vs. subjective and quantitative vs. qualitative data and analytical tools in their conceptualization and implementation. This endeavor is undertaken in the context of recent attempts to shift through various pitfalls and prospects, towards a more concerted, integrative approach to LCA development and practice, both appropriate to its challenges and adaptable to time-space-culture-discipline landscape particularities and means of implementation. The importance of the study lies in its attempt to provide a framework for more integrative and balanced, but also critical and flexible, implementation of the LCA in landscape planning, management, research, and education.

\section{Theoretical Considerations}

\subsection{Basic Constituent Elements of LCA and LCA Practices in Europe}

Landscape character assessment is a set of techniques and procedures and a recognized tool for the classification and description of landscape, also used to understand the evolution of its physical and cultural characteristics $[5,10]$. Many variations of LCA are used across Europe, due to different policies, their interactions with stakeholders, their links to efforts towards the development of landscape indicators, and the various scientific and technical bases of data collection. Groom et al. define landscape character as "distinct and consistent patterns of elements in the landscape" and LCA as "a set of tools that are scientifically sound, region-specific and stakeholder orientated, designed to describe landscape character ... a process concerned primarily with documenting landscape character rather than assigning quality or value" [11]. Briefly, LCA as a method combines "subjectivity and objectivity and as a process of characterization is objective, while making judgements to inform decisions involve an element to subjectivity" [12]. Therein lies the 
challenge of the LCA, how to combine best the employment of both quantitative and qualitative data towards these goals.

LCA has a long history in Europe, with the most representative examples of such work in NW European countries [13]. In very recent years, significant progress has also been made in the Southern European/Mediterranean region, regarding the description and mapping of landscape types $[5-7,14,15]$. At the same time, augmenting policy, and management needs for more detailed and accurate landscape typologies, at least at the European level, have led to efforts towards standardizing LCA. The latter typologies aim to reduce uncertainty and subjectivity in assessing and characterizing landscape, to curb personal judgement and to produce indicators/tools of both quantitative and qualitative data analysis, in an effort to arrive at a holistic and combinational approach to landscape characterization. In this context, a series of landscape indicators have been developed that describe, evaluate, and communicate relevant aspects such as the state of landscapes, their evolution, the landscape policies implemented by public institutions, citizen involvement in landscape matters, or the degree of awareness and enjoyment of the landscape by the population, but also visual landscape quality and experiential, perceptual, or value-based landscape aspects [16-23]. Several countries "have chosen a rather proactive approach towards the implementation of indicator-based landscape assessment and have developed methodologies in terms of spatial resolution and policy orientation, resulting in impressive monitoring and reporting products at the national level. Meanwhile, geographic information systems (GIS) and remote sensing have given geographers and ecologists unique capacity to quantify land cover pattern and understand spatial heterogeneity and landscape structure" [24,25].

The purpose of landscape characterization [8] is to identify areas of distinct character, to classify and map them, and to describe their character and key characteristic features. To achieve this, identification of landscape types in the area is required. The latter are derived through a structured approach/method, based on the combination of physical (relief, geology, soils, habitats/vegetation) and cultural factors (land use and settlement) [6,26], which helps render these landscape descriptions professional and objective [26]. Recent inroads into new technologies, such as the Web and geographical information systems (GIS), have managed to render these landscape descriptions more readily transferrable into policy outcomes.

The landscape character assessment process includes three stages: (a) The desk study, (b) the fieldwork, and (c) the classification of landscape description units-LDUs- and amalgamation of landscape types. Landscape description units are distinct and relatively homogenous units of land, each defined by a series of definitive attributes (soil, geology, topography, land cover, settlement pattern) [13], The desk study is based on: (1) The review of relevant background reports, other qualitative and quantitative data, and mapped information, (2) the application of this information to the creation of a series of map overlays of landscape factors for the area of interest, based on primary data already collected by other national/international public bodies, and (3) the first draft definition of LDUs, which, most of the time, relies on the compilation of the above layers as produced with GIS. The fieldwork aims to: (1) Gain an overall impression of the visual character of the landscape, which relies on the subjective perception of the observer, (2) amend the boundaries of the mapped LDUs, as appropriate, either with the aid of GIS or by the subjective opinion of the researcher, (3) record (i.e., photograph) the landscape and its characteristic features, and (4) complete a field assessment sheet for each landscape unit, in situ, where, again, the judgements are mostly subjective. The classification of the LDUs and creation of landscape types includes: (1) The adjustment/correction of LDUs and their cartographic presentation, if needed, which, again, relies on the perception of the researcher, (2) the creation and mapping of landscape types, either manually or through GIS analysis/fieldwork observation/post-GIS analysis and interpretation methods and tools, and (3) the finalization of the description of the landscape types and their particular features. 


\subsection{The Challenge of Objective vs. Subjective and Quantitative vs. Qualitative in LCA}

Nonetheless, top-down expert landscape analysis and interpretation are fraught with challenges potentially leading to overly subjective conclusions, whereas sole- or over-reliance on objective approaches runs the risk of glossing over diversity and of overgeneralization of spatial data and resulting landscape units. Another risk of measuring attributes from maps and analyzing the data solely quantitatively is to lose the sense of place, quintessential to landscape conceptualization and living in the landscape-not to mention perceptual, artistic/literary, experiential, and value-laden landscape aspects/elements. Quantitative methodologies using semantic rating scales and cluster analyses ([27] and qualitative methodologies such as household surveys and public perception tools [28] have tended to be combined for better results. In addition, photograph validation comparing results of field and non-field responses has been used by several researchers [29-31] and contested by others [32-34]), on the basis of their use in isolation and emphasis on the visual component, in the context of the overall subjectivity involved in deciding the scale, boundaries, and content of the selected photographs. Quite often, policy implementation schemes are also based on experiential research using other qualitative methods, such as virtual individual decision maps comprising a final composite area map ([35], or scenariobased studies where the public is presented with visual representations of possible future landscapes, with a more explicit policy focus [36,37]). The process of deciphering objective vs. subjective aspects of LCA and distinguishing between quantitative vs. qualitative data in proper LCA development and implementation therefore entails several risks and challenges, aptly laid out by Swanwick [10]:

There has been long-standing debate about the role of objectivity and subjectivity in dealing with landscape. The search for supposedly objective approaches has reflected a desire, in some quarters, to remove the element of personal judgement from the process ... In Landscape Character Assessment it is accepted that there is a role for subjective inputs, but these must be made in a systematic and transparent way. The process of characterization should be an objective process in the main, while making judgements to inform decisions involves an element of subjectivity which can be clarified by using criteria agreed beforehand. The important thing is that everyone involved in the process, or in the use of an assessment, understands which elements of it are relatively objective and unlikely to be disputed, and which ones are more likely to be viewed differently by different stakeholders. There is also scope for a wide range of stakeholders to contribute to characterization, each contributing their own judgements about variations in character.

Therefore, and as a general rule, as a tool primarily aimed towards landscape identification/categorization and mapping, LCA relies foremost on quantitative data, which are omnipresent and ubiquitous in any type or form of LCA. Normally, quantitative data already exist as primary data available for LCA implementation, as they serve a broad variety of societal functions and uses (environmental, ecological, planning, etc.), for purposes of compliance with policy and directives, at least at the EU level. Furthermore, qualitative data are an integral part of LCA, stemming from the landscape definition and conceptualization itself, and are necessary, as already indicated above, in describing the "character" of a landscape. Further, as a tool, LCA requires a multidisciplinary team of experts for its operationalization and implementation. Another problem in bigger-scale projects is the accuracy of boundaries among the LDUs as well as of the cartographical data. Qualitativeness is thus employed in various forms of LCA, and specifically as landscape elements, functions, dimensions or methodologies used to "measure" LDUs complement the quantitative aspects of LCA, i.e., the historic and built environment, and some matters of perception such as the sense of enclosure, tranquility, or remoteness. Such examples of qualitativeness are landscape indicators of visual qualities $[19,20]$ based on frameworks stemming from aesthetic theory, for purposes of visual landscape quality and character assessment [21,22], or the Catalonian landscape catalogues, which aim at integrating natural and cultural values in their tangible and intangible dimensions [38]. However, the latter authors also caution that: 
Landscape is, to a great degree, concerned with experience, that is to say, it is formed from the sum of experiences lived through over the years, with deep-rooted feelings of belonging and identity. The ancestral social and economic relationship established between the various populations of a territory, or between a village and a nearby river, the use of certain techniques and practices in dealing with crops, the names of places, the existence of a dialect spoken in a little area and the special recognition of certain landscapes (through their importance during childhood or through their daily use) are, among others, some of the factors - now intangible — which identify us with a particular landscape.

These aspects of subjectivity, then, ought to be combined with more objective data, in LCA formulation and implementation, and they also ought to encompass collective humanlandscape interrelationships, not just personal assessments. For instance, the "feeling of a place/landscape" is not enough. "For the identification of the more cultural, perceptive, and interpretative values (such as the aesthetic, symbolic and spiritual) and, therefore, more subjective in evaluation, it is very important to know the opinions of the people who live in a territory, through enquiries both general and directed to informed people" [38]. Such subjective data come into play, in various ways, in LCA methodologies, starting with the selection of the best fit LCA version (i.e., degree of interdisciplinarity, reliance on other information beyond the method itself or not, etc.), coupled with the datasets to be utilized (i.e., GIS, statistical/numerical, tangible and intangible). Subjective decisions run the spectrum of the justification of the specific LCA method, of its adjustment to the timespace-society particulars of the context of its implementation, of the acknowledgement of its delimitations, of case study and survey site selection, of field-study strategy and site reconnaissance, of synthesizing all the data into landscape units and character types, of naming them, and, last but not least, of the ways of involving all relevant stakeholders, including locals and expert informers in the whole process (i.e., landscape and community acquaintance, planning, deliberating, reporting, decision-making, implementation). LCA methodologies may also "differ substantially depending on traditions of geographical and landscape research, the practical purpose of the mapping and landscape characteristics of the country" [6,39], as well as the needs of landscape planning and management and respective community priorities.

\section{Research Design}

Based on a broad literature review of the ways in which the objective/subjective and the quantitative/qualitative variables ("our 2-variable scheme") interweave in currently practiced or proposed versions of LCA, this paper employs the method of meta-analysis, to examine the fit of these 2 variables into the co-creation of LCA. Our main research question was, "How do LCA methodologies negotiate the interplay between objective and subjective landscape dimensions, with the aid of quantitative vs. qualitative approaches and data?"

After an extensive theoretical overview of pertinent literature over the past 20 years, we created our database format and proceeded to the meta-analysis of these bibliographical sources, with the aid of our 2-variable scheme model of LCA classification. Specifically, the meta-analysis focused on a critical assessment of the recent evolution, methods, concessions, and risks of such endeavors, and aimed at charting them on an integrative conceptual model, developed for the purpose of analyzing the interplay between objectivesubjective and quantitative-qualitative constituent parts of existing LCA methodologies. We concluded with the interpretation of results, based on the position our bibliographical sources took on our 2-way 2-variable scheme and a discussion of issues of applicability and contribution of this model to LCA analysis, in light of the study's findings/results.

Our literature search comprised all references that we located, relevant to LCA methodologies in theory or practice and to landscape assessment/characterization/mapping methods, more generally, provided they were available in digital form and written or translated into English. The meta-data of our database comprised 46 scientific sources (Table 1), namely articles, book chapters, books, or research project reports, which were selected from a much larger pool of sources, as best fitting our search criteria. The criteria of inclusion in 
the database were any combination of the following: (1) Expression of dilemmas, barriers, and debates vis-a-vis LCA-related subjective-objective or qualitative-quantitative aspects, (2) review/presentation of case studies of implementation of LCA methods and tools in Europe and elsewhere, and (3) LCA application in landscape management, including employment of any of the levels of measurement of the 2 variables. All such sources pertaining to LCA since roughly 2000 were included in the study and analyzed for the following: (a) Employment of qualitative/quantitative data and subjective/objective methods and tools, (b) explicit or implicit analysis and/or discussion of the weight placed on the above data and methods/tools, as well as on their interrelationships, and (c) rating of the sources according to our 2-variable scheme.

Table 1. The database of bibliographical sources used for the meta-analysis.

\begin{tabular}{|c|c|c|c|}
\hline Cryptic_ID & SOURCE & RESEARCH THEME & $\begin{array}{l}\text { CASE STUDYI } \\
\text { COUNTRY }\end{array}$ \\
\hline Groom & Groom et al. (2003) [11] & $\begin{array}{l}\text { A comprehensive review of LCA case studies } \\
\text { from around Europe. LCA comprises both } \\
\text { objective and subjective and quantitative and } \\
\text { qualitative factors and methods, with a strong } \\
\text { emphasis (highest proportion) of objective and } \\
\text { quantitative ones }\end{array}$ & Pan-European study \\
\hline Swanwick & Swanwick (2002) [10] & $\begin{array}{l}\text { A detailed report on LCA in Great Britain and } \\
\text { its application }\end{array}$ & England and Scotland \\
\hline Eurostat & $\begin{array}{l}\text { Eurostat; DG Agriculture; DG } \\
\text { Environment; Joint Research } \\
\text { Center; European Environment } \\
\text { Agency (2001) [40] }\end{array}$ & $\begin{array}{l}\text { A better integration between quantifiable and } \\
\text { non-quantifiable elements/aspects of the } \\
\text { landscape is advocated for purposes of better } \\
\text { interpretation of landscape state indices }\end{array}$ & $\begin{array}{l}\text { UK, France, Spain, } \\
\text { Denmark, Germany, Italy, } \\
\text { Portugal, Estonia }\end{array}$ \\
\hline Martin & Martin et al. (2007) [41] & $\begin{array}{l}\text { Review and comparison of LCA } \\
\text { methodologies through a SWOT analysis }\end{array}$ & Ireland/Europe \\
\hline Agency & $\begin{array}{l}\text { The Countryside Agency } \\
\text { (2002) [42] }\end{array}$ & $\begin{array}{c}\text { An introduction to the use of GIS in LCA } \\
\text { including examples of good practice and } \\
\text { case studies }\end{array}$ & England and Scotland \\
\hline Tudor & Tudor (2014) [43] & $\begin{array}{l}\text { A great example of an effort to interweave all } \\
\text { aspects of our 2-variable scheme in a tight, } \\
\text { systematic, and multilayered approach to LCA }\end{array}$ & Wales \\
\hline Vogiatzakis & Vogiatzakis (2011) [5] & $\begin{array}{l}\text { Review of LCA across the Mediterranean } \\
\text { countries (pros and cons) }\end{array}$ & Mediterranean \\
\hline ESPON & ESPON (2015) [44] & $\begin{array}{l}\text { The analysis here is on the contribution of } \\
\text { landscape to liveability. The outcomes are } \\
\text { criteria for successfully integrating landscape } \\
\text { planning and management into } \\
\text { spatial planning. }\end{array}$ & Europe \\
\hline Wascher & Wascher (2005) [45] & $\begin{array}{l}\text { Analysis of national landscape } \\
\text { classifications/typologies has shown the partly } \\
\text { great distinctions between European countries. } \\
\text { The LANMAP2 represents a new generation of } \\
\text { landscape classification and mapping }\end{array}$ & Europe \\
\hline UK review & King (2009) [46] & $\begin{array}{l}\text { The national landscape countryside character } \\
\text { typology for England }\end{array}$ & Gloucestershire, England \\
\hline Gkoltsiou & Gkoltsiou et al. (2013) [23] & $\begin{array}{l}\text { Landscape indicators to measure tourism } \\
\text { landscape structure }\end{array}$ & Greece \\
\hline Jaber & Jaber et al. (2015) [47] & $\begin{array}{l}\text { Introducing a new LCA method adjusted to } \\
\text { the East Mediterranean countries }\end{array}$ & $\begin{array}{l}\text { East Mediterranean } \\
\text { countries }\end{array}$ \\
\hline
\end{tabular}


Table 1. Cont.

\begin{tabular}{|c|c|c|c|}
\hline Cryptic_ID & SOURCE & RESEARCH THEME & $\begin{array}{l}\text { CASE STUDY/ } \\
\text { COUNTRY }\end{array}$ \\
\hline Tsilimingkas & Tsilimingkas(2014) [48] & $\begin{array}{c}\text { A good example of integrative } \\
\text { landscape planning/management/ } \\
\text { policy review of the state-of-the-art } \\
\text { in Greece }\end{array}$ & Greece \\
\hline Kolejka & Kolejka \& Lipský (2008) [6] & $\begin{array}{l}\text { Landscape mapping and typology in } \\
\text { the Czech Republic }\end{array}$ & Czech Republic \\
\hline Scott & Scott (2003) [39] & $\begin{array}{l}\text { Bottom-up approach to LCA } \\
\text { methodologies and public landscape } \\
\text { perception, based on an assessment of } \\
\text { the findings of a survey, allowing for } \\
\text { valuable insights to be gained with } \\
\text { respect to the way that the public view } \\
\text { their landscapes (in the context of the } \\
\text { LANDMAP project) }\end{array}$ & $\begin{array}{l}\text { Case studies: Selected } \\
\text { areas of Wales, but } \\
\text { theoretical review of LCA } \\
\text { methodologies and public } \\
\text { perception = international }\end{array}$ \\
\hline Warnock & Warnock \& Griffiths (2014) [49] & $\begin{array}{l}\text { Presentation of an LCA method in } \\
\text { order to overcome the lack of } \\
\text { consistency among the LCAs } \\
\text { across Europe }\end{array}$ & UK \\
\hline Uzun & Uzun et al. (2011) [50] & Presentation of LCA applied in Turkey & $\begin{array}{l}\text { Turkey: (1) Konya closed } \\
\text { basin, (2) Suğla Lake }\end{array}$ \\
\hline MEDSCAPES & MEDSCAPES (2015) [51] & $\begin{array}{l}\text { Introducing a new LCA method } \\
\text { adjusted to the East } \\
\text { Mediterranean countries }\end{array}$ & $\begin{array}{c}\text { East Mediterranean } \\
\text { countries (Cyprus, Greece, } \\
\text { Jordan, and Lebanon) }\end{array}$ \\
\hline Brunetta & Brunetta \& Voghera (2008) [52] & $\begin{array}{l}\text { It points out the need for a balance } \\
\text { among subjective and objective } \\
\text { assessment methods and tools }\end{array}$ & $\begin{array}{l}\text { The Netherlands, UK, } \\
\text { France, Italy, Spain, } \\
\text { Slovenia, Denmark, }\end{array}$ \\
\hline Trop & Trop (2017) [53] & $\begin{array}{l}\text { Reference to the main weaknesses } \\
\text { of LCA }\end{array}$ & Israel \\
\hline Herlin & Herlin (2016) [54] & $\begin{array}{l}\text { It argues about the landscape } \\
\text { sensitivity studies based on LCA as } \\
\text { well as its pros and cons }\end{array}$ & England \\
\hline
\end{tabular}

The biggest challenge remains finding methods that facilitate at various scales the integration into HLC or LCA of

Cornwall, England

Fairclough1 Fairclough et al. (2016) [55] public, non-expert views of landscape.

Interesting issue of temporality in the three case study areas

UK, France, Sweden

The landscape character concept is a significant one because it can help us to

Dalglish Dalglish \& Leslie (2016) [57] translate the principle of sustainable development into action in particular localities

Landscape character assessments

Primdahl Primdahl \& Kristensen (2016) [58] playing a central role in this process

Primdahl Primdahl \& Kristensen (2016) [58] playing a central role in this

It argues about the significance of the assessment document for planning

Scotland

Butler1 $\quad$ Butler (2016) [59]


Table 1. Cont.

\begin{tabular}{|c|c|c|c|}
\hline Cryptic_ID & SOURCE & RESEARCH THEME & $\begin{array}{l}\text { CASE STUDY/ } \\
\text { COUNTRY }\end{array}$ \\
\hline Olwig & Olwig (2016) [60] & $\begin{array}{l}\text { The arguments for the rewilding of the } \\
\text { Lake District resemble Linné's notion of } \\
\text { nature's economy as a form of a } \\
\text { self-regulating and purposeful (i.e., } \\
\text { teleological) service-providing } \\
\text { eco(nomic) and bureaucratic } \\
\text { managerial system }\end{array}$ & UK, Lake District \\
\hline Van Eetvelde & Van Eetvelde \& Antrop (2009) [61] & $\begin{array}{c}\text { The method presented is a combination } \\
\text { of the parametric and holistic } \\
\text { methods used }\end{array}$ & Belgium \\
\hline Aretano & Aretano et al. (2013) [62] & $\begin{array}{l}\text { In this study, results of landscape } \\
\text { change detection are compared in } \\
\text { terms of ecosystem service flow } \\
\text { (objective assessment) with the } \\
\text { investigation on people's perception } \\
\text { (subjective assessment) }\end{array}$ & Italy \\
\hline Guo & Guo \& Zhang (2017) [63] & $\begin{array}{l}\text { GIS, Gower's similarity coefficient, and } \\
\text { the AP algorithm were used to identify } \\
\text { landscape character types at two levels } \\
\text { for transregional integration in the } \\
\text { multi-ethnic area of Wuling Mountain }\end{array}$ & China \\
\hline Jellema & Jellema et al. (2009) [64] & $\begin{array}{c}\text { This is basically a methodology based } \\
\text { on the spatial analysis tool for LCA. It } \\
\text { introduces objectivity but the paper } \\
\text { does not refer to objectivity or } \\
\text { subjectivity of LCA }\end{array}$ & Netherlands \\
\hline Belen & Belen et al. (2016) [65] & $\begin{array}{l}\text { This is basically a methodology based } \\
\text { on indicators; GIS for LCA }\end{array}$ & Madrid, Spain \\
\hline Mahan & Mahan \& Mansouri (2017) [66] & $\begin{array}{l}\text { The research argues upon the } \\
\text { evaluations and studies in the field } \\
\text { of landscape }\end{array}$ & Tehran, Iran \\
\hline Alfred & Alfred (2005) [67] & $\begin{array}{c}\text { Short mention to the historic landscape } \\
\text { assessment as subjective and } \\
\text { objective method }\end{array}$ & Iceland \\
\hline Butler2 & Butler \& Berglund (2014) [68] & $\begin{array}{l}\text { Landscape character assessment as an } \\
\text { approach to understanding public } \\
\text { interests within the European } \\
\text { Landscape Convention }\end{array}$ & Sweden \\
\hline Caspersen & Caspersen (2008) [69] & $\begin{array}{l}\text { The objectives of this study were to } \\
\text { investigate how participatory methods } \\
\text { may enhance LCA }\end{array}$ & Denmark \\
\hline Fairclough & Fairclough (2002) [70] & $\begin{array}{l}\text { HLC uses area-based generalizations } \\
\text { within a GIS environment to produce } \\
\text { an overview of an area's broad } \\
\text { landscape character }\end{array}$ & England \\
\hline Fairclough2 & Fairclough et al. (2018) [71] & $\begin{array}{l}\text { An overview for practitioners and } \\
\text { policymakers of the current range of } \\
\text { methods that exist for characterizing } \\
\text { landscape in Europe and in the } \\
\text { wider world }\end{array}$ & Global \\
\hline
\end{tabular}


Table 1. Cont.

\begin{tabular}{|c|c|c|c|}
\hline Cryptic_ID & SOURCE & RESEARCH THEME & $\begin{array}{l}\text { CASE STUDY/ } \\
\text { COUNTRY }\end{array}$ \\
\hline Swanwick & $\begin{array}{l}\text { Swanwick and Fairclough } \\
\text { (2018) [72] }\end{array}$ & $\begin{array}{l}\text { A historical overview of the evolution } \\
\text { of the LCA methodology in the UK }\end{array}$ & Britain \\
\hline Herlin & Herlin et al. (2018) [73] & $\begin{array}{l}\text { This article contains a historical } \\
\text { overview of the employment of LCA in } \\
\text { Nordic countries }\end{array}$ & Sweden, Nordic countries \\
\hline Atik & Atik and Karadeniz (2018) [74] & $\begin{array}{l}\text { A description of LCA application } \\
\text { in Turkey }\end{array}$ & Turkey \\
\hline Warnock & Warnock et al. (2018) [75] & LCA application in the case of Cyprus & Cyprus \\
\hline Andlar & Andlar and Aničić (2017) [76] & $\begin{array}{l}\text { The research presents the experience of } \\
\text { compiling a register of outstanding } \\
\text { cultural landscapes in the Adriatic } \\
\text { coastal zones of Croatia }\end{array}$ & Croatia \\
\hline Loupa & $\begin{array}{l}\text { Loupa-Ramos and Pinto-Correia } \\
\text { (2018) [77] }\end{array}$ & $\begin{array}{l}\text { The research aims to report on the } \\
\text { experience of carrying out landscape } \\
\text { character (LC) assessment at multiple } \\
\text { scales in Portugal since } 2000\end{array}$ & Portugal \\
\hline Käyhkö & Käyhkö et al. (2018) [78] & $\begin{array}{l}\text { This chapter describes the landscape } \\
\text { character mapping and assessment } \\
\text { process which was initiated in } 2012 \text { in } \\
\text { Zanzibar, for the islands of Unguja } \\
\text { and Pemba }\end{array}$ & Zanzibar \\
\hline Palmer & Palmer and Smardon (2018) [79] & $\begin{array}{l}\text { The research has considered the US } \\
\text { federal approach to landscape character } \\
\text { assessment }\end{array}$ & USA \\
\hline
\end{tabular}

Metadata is the technical term for "data about data", used to describe the summary information or characteristics of a dataset, while meta-analysis is the research method that combines the results of several related studies to produce better results [29]. More specifically, our meta-database structure consisted of the following information: 1. Bibliographical source, 2 . website, 3. reviewer, 4 . reference to our 2-vatiable scheme, 5. reference description, 6 . interrelations between the 2 variables, 7 . case studies/scale, 8 . other/general comments, 9. measurement on the objective-subjective scale, and 10. measurement on the quantitative-qualitative scale.

Following the measurement of objective vs. subjective and quantitative vs. qualitative aspects (our 2-variable scheme) (Figure 1, Table 2) of our 46 LCA sources on a 5-pt scale, we placed these studies/sources on a conceptual model created to illustrate the degree of/and relationships between our two variables. The conceptual model of the axes of the 2-variable scheme that we developed included $5 \times 5=25$ possible locations, divided into two dimensions. Each source was categorized simultaneously as regards both its objective/subjective dimension as well as its qualitative/quantitative dimension. Limits between possible "locations" in this two-dimensional conceptual space were based on the authors' scientific experience in this area of study, as shown in Table 2. The 5 intervals (on both axes) were selected as an ideal small-scale categorization, with a distinct neutral category (category 3 out of 5 ) and two additional categories on each side $(1,2)$ and $(4,5)$. 


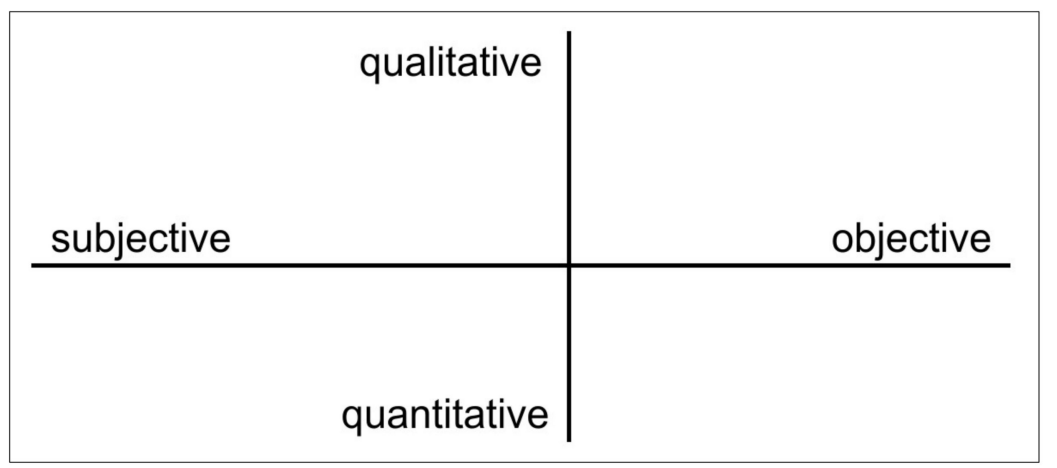

Figure 1. The conceptual model. The axes of the 2-variable scheme.

Table 2. The 2-variable scheme and explanation of levels of measurement.

\begin{tabular}{ccl}
\hline Level of Measurement & & \multicolumn{1}{c}{ Explanation } \\
\hline Very Objective & $\bullet$ & $\begin{array}{l}\text { Employment of or advocacy for only objective methods } \\
\text { No consideration of subjective methods/approaches/tools in LCA analysis or implementation }\end{array}$ \\
\hline Objective & $\bullet$ & $\begin{array}{l}\text { Acknowledgement and/or consideration of subjective methods/approaches/tools, but } \\
\text { employment mainly/mostly of objective methods in LCA analysis or implementation }\end{array}$ \\
\hline Neutral & $\bullet$ & $\begin{array}{l}\text { Approximately equal degree of acknowledgment, consideration, and/or employment of both } \\
\text { objective and subjective methods/approaches/tools in LCA analysis or implementation }\end{array}$ \\
\hline Subjective & $\bullet$ & $\begin{array}{l}\text { Acknowledgement and/or consideration of objective methods/approaches/tools, but } \\
\text { employment mainly/mostly of subjective methods in LCA analysis or implementation }\end{array}$ \\
\hline Very Subjective & $\bullet$ & $\begin{array}{l}\text { Employment of or advocacy for only subjective methods/approaches/tools } \\
\text { No consideration of objective methods in LCA analysis or implementation }\end{array}$ \\
\hline Very Quantitative & $\bullet$ & $\begin{array}{l}\text { Employment of or advocacy for only quantitative methods } \\
\text { No consideration of qualitative methods/approaches/tools in LCA analysis or implementation }\end{array}$ \\
\hline Quantitative & $\bullet$ & $\begin{array}{l}\text { Acknowledgement and/or consideration of qualitative methods/approaches/tools, but } \\
\text { employment mainly/mostly of quantitative methods in LCA analysis or implementation }\end{array}$ \\
\hline Neutral & $\bullet$ & $\begin{array}{l}\text { Approximately equal degree of acknowledgment, consideration, and/or employment of both } \\
\text { quantitative and qualitative methods/approaches/tools in LCA analysis or implementation }\end{array}$ \\
\hline Qualitative & $\bullet$ & $\begin{array}{l}\text { Acknowledgement and/or consideration of quantitative methods/approaches/tools, but } \\
\text { employment mainly/mostly of qualitative methods in LCA analysis or implementation }\end{array}$ \\
\hline Very Qualitative & $\bullet$ & $\begin{array}{l}\text { Employment of or advocacy for only qualitative methods/approaches/tools } \\
\text { No consideration of quantitative methods in LCA analysis or implementation }\end{array}$ \\
\hline
\end{tabular}

The meta-analysis of the 46 articles was conducted by the three authors as shown in the following tables (Tables 3-5). This approach offers a degree of diversity in approaching and conceptualizing landscape-related literature. All three authors (experts) have been involved in landscape-related research in the past. Authors 1 and 2 have more general landscapeoriented scientific profiles, while author 3 has a more quantitative landscape-oriented research profile. Tables 3-5 depict the results of the categorization of our 46 landscaperelated sources by author. There exists a clear similarity in these results between authors 1 and 2, while author 3 shows a somewhat different perspective of the reviewed sources. The sources were allocated randomly to the three authors; the chronological distribution of the sources by author is depicted in Figure 2. Based on Figure 2, the chronological distribution of sources by author is balanced and is a result of this random allocation. 
Table 3. Author 1 sources (18 sources).

\begin{tabular}{llccccc}
\hline & & (1) Very Quantitative & (2) Quantitative & (3) Neutral & (4) Qualitative & (5) Very Qualitative \\
\hline 5. & Very Subjective & 1 & 0 & 0 & 1 & 0 \\
4. & Subjective & 0 & 0 & 0 & 0 & 0 \\
3. & Neutral & 0 & 0 & 11 & 0 & 0 \\
2. & Objective & 1 & 1 & 0 & 0 & 0 \\
1. & Very Objective & 0 & 3 & 0 & 0 \\
\hline
\end{tabular}

Table 4. Author 2 sources (18 sources).

\begin{tabular}{llccccc}
\hline & & (1) Very Quantitative & (2) Quantitative & (3) Neutral & (4) Qualitative & (5) Very Qualitative \\
\hline 5. & Very Subjective & 0 & 0 & 0 & 0 & 0 \\
4. & Subjective & 0 & 0 & 0 & 0 & 0 \\
3. & Neutral & 0 & 1 & 0 & 0 & 0 \\
2. & Objective & 0 & 2 & 0 & 0 & 0 \\
1. & Very Objective & 3 & 3 & 0 & 0 \\
\hline
\end{tabular}

Table 5. Author 3 sources (10 sources).

\begin{tabular}{|c|c|c|c|c|c|c|}
\hline & & (1) Very Quantitative & (2) Quantitative & (3) Neutral & (4) Qualitative & (5) Very Qualitative \\
\hline 5. & Very Subjective & 0 & 0 & 0 & 0 & 0 \\
\hline 4. & Subjective & 0 & 1 & 0 & 0 & 0 \\
\hline 3. & Neutral & 0 & 2 & 2 & 0 & 1 \\
\hline 2. & Objective & 0 & 3 & 0 & 1 & 0 \\
\hline 1. & Very Objective & 0 & 0 & 0 & 0 & 0 \\
\hline
\end{tabular}



Figure 2. Year of source by author.

In our effort to demonstrate visually the distribution of all sources across the twodimensional "space" of objective/subjective and quantitative/qualitative, we developed the following illustration (Figure 3). This is a two-dimensional abstract "space" with predefined locations (grey squares) of all $5 \times 5=25$ possible combinations of the above two scales. Sources were allocated to these predefined locations, forming a 2D distribution 
of points. We used " $\mathrm{R}$ " statistical programming language for the allocation of sources to this $2 \mathrm{D}$ abstract space. Furthermore, in the following Table 6, we present the frequencies of sources over the two scales [80].



Figure 3. The meta-analytical position of the study's bibliographical sources on the conceptual model. The sources appear on the model as the surnames of their principal authors.

Table 6. Two-way frequency table of sources per subjective/objective and quantitative/qualitative dimension of approach.

\begin{tabular}{llccccc}
\hline & & (1) Very Quantitative & (2) Quantitative & (3) Neutral & (4) Qualitative & (5) Very Qualitative \\
\hline 5. & Very Subjective & 1 & 0 & 0 & 1 & 0 \\
4. & Subjective & 0 & 1 & 0 & 1 & 0 \\
3. & Neutral & 0 & 3 & 0 & 1 & 1 \\
2. & Objective & 1 & 6 & 0 & 0 & 0 \\
1. & Very Objective & 3 & 6 & & 0 \\
\hline
\end{tabular}

\section{Meta-Analysis and Discussion of Findings}

Based on the above results, without considering the neutral categories of both axes, 16 papers seem to be located in the lower left part/quadrant of the graph, indicating an "objective" aspect and a "quantitative" approach (Table 6). The upper left (quantitative and subjective) and upper right (qualitative and subjective) quadrants of the graph both include two papers. Finally, the lower right part of the graph (qualitative and objective) includes one single paper. The distribution of the 25 sources in the central row and column of the graph indicates their rather balanced approach of the LCA method around neutrality, in both dimensions. There seems to be a somewhat heavier balancing (a concentration) towards objectivity with quantitative approaches in the lower left part of the graph. These findings are in accordance also the results of our overview of the recent historical evolution of LCA research and practice, presented below.

The most striking finding of our meta-analysis was, thus, the high degree of concentration of our bibliographical sources at the bottom left and the central part of our 
conceptual model, indicating an almost clear linear relationship between our 2 axes, at least as far as the quantitative approaches tended to correlate with objective approaches. Such a conclusion is, of course, rather tentative and drawn with much caution, due to the small number of levels of measurement (5 each) of our two scales: (1) Very quantitative, (2) quantitative, (3) neutral, (4) qualitative, (5) very qualitative and (1) very objective, (2) objective, (3) neutral, (4) subjective, (5) very subjective. Nonetheless, these concentrations are very significant (Figure 4), and the rest of our bibliographical sources appear as outliers to this pattern, on the diagram of our model. Furthermore, several other issues came up, in the course of our meta-analysis, as follows.

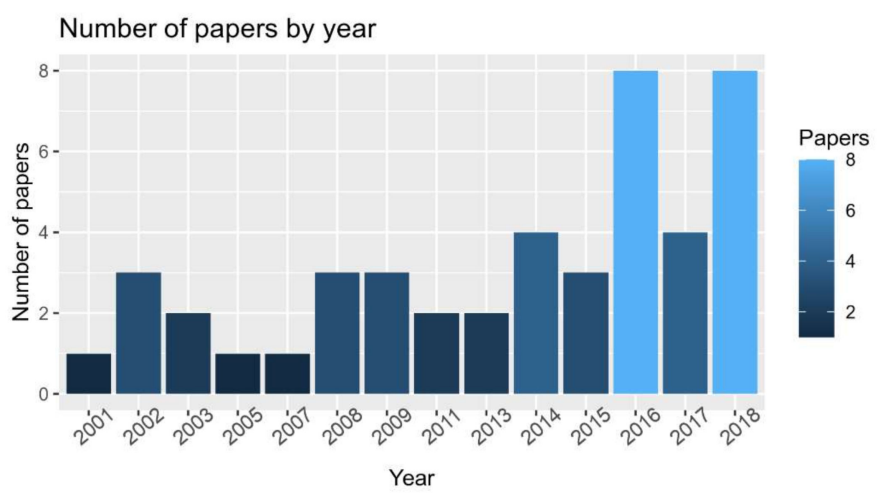

Figure 4. Number of papers per year.

To begin with, deciphering the pertinent terminology may be a daunting task. Specifically, terms were often used by our sources indiscriminately, alternatively, or as synonyms, i.e., nominal or factual for qualitative; expert judgement, extrinsic, or interpretive for subjective; characterization, automated derivation, mechanistic-analytical, intrinsic, or value-free for objective. Other in-between terms that further complicated our analysis were: Interactive refinement; top-down vs. bottom-up. Other polarities included landscape facts vs. landscape values/sensitivity, etc., as well as biophysical vs. aesthetic/experiential/perceptual factors. We assessed these terms and polarities by harmonizing them with our 2-variable scheme, as/if appropriate, without comprising their integrity. Significantly, a chronological evolution of the weight of the two poles of our 2-variable scheme in LCA theory and practice emerged from our meta-analysis, as shown in Figure 4.

A clear historical progression towards more quantitative and objective approaches became apparent, although qualitative and subjective approaches have also remained significant to date, i.e., increasing emphasis on landscape physicality, but also on relationships and practices, as well as on land use and land cover, but also on economic and recreational landscape values [81]. Additionally, increasing emphasis has been being placed on public/stakeholder participatory methods (landscape justice, democracy, etc.). The following figures (Figures 5 and 6) depict the chronological distribution of our sources on the basis of the objective/subjective dimension, as well as the quantitative/qualitative dimension. Figure 5 indicates a rise in objective and very objective sources over the past 20 years, while Figure 6 shows a shift from neutral and qualitative approaches towards more quantitative approaches, during that same time period. These trends mainly indicate a higher and increasing number of studies using quantitative and objective LCA methods, as opposed to than qualitative and subjective approaches, which seem to remain rather stable in number. Neutral approaches appear to remain constantly significant over time.

However, the primary ever-present tension does not cease to exist, in the course of these two recent decades. On the one hand, stakeholder involvement is considered paramount in LCA, as it encourages ownership of the study and successful subsequent action on landscape issues. On the other hand, commonly agreed-upon approaches to landscape classification (i.e., LANMAP), especially when referring to cases of extensive 
areal coverage, seem to move away from a subjective, intuitive, and qualitative approach towards a more formal, objective, and quantitative standardized system [33].

A distinction emerged also as regards the predominance of different values of our 2variable scheme in LCA theory and practice, depending on the purpose/scope of the study: More qualitative and subjective approaches seem to have been used in applications to plan and landscape stewardship (i.e., sustainable development, environmental protection, risk assessment) vs. for theoretical/scientific purposes. One such example is LANMAP2, a new generation of landscape classification and mapping, demonstrating how traditional methods could be complemented by computer-driven methods, new techniques and European-wide datasets, for standardizing landscape classifications, in order to produce more comparable, more transparent, more reproducible, and to some degree more objective and accurate results [33].

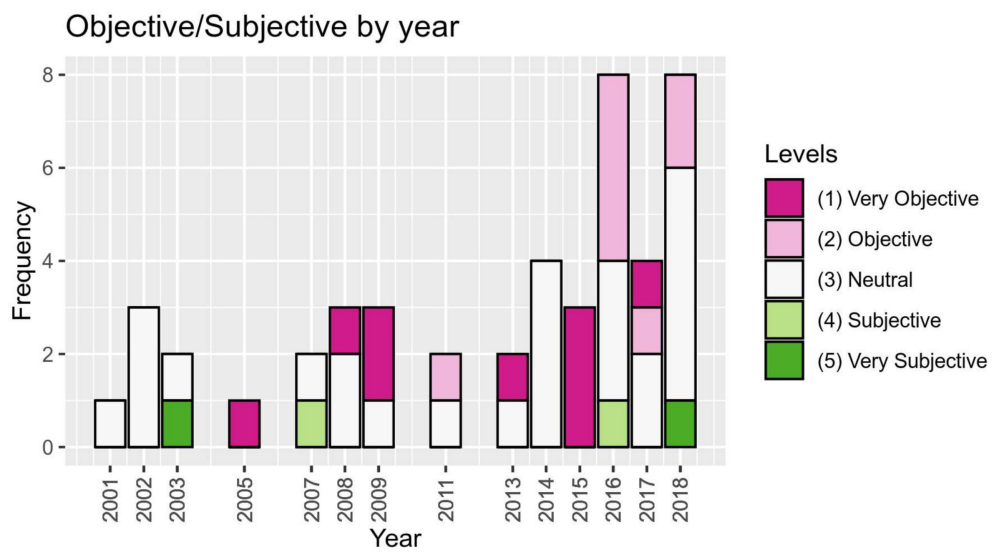

Figure 5. Frequency of sources based on levels of objective/subjective dimension over the past 20 years.



Figure 6. Frequency of sources based on levels of quantitative/qualitative dimension over the past 20 years.

Although scale was not one of our analytical variables, our study reaffirms that the issue of scale remains paramount and tightly linked to the LCA methodology, i.e., overlaying GIS data sets for landscape mapping guarantees objectivity at the national or supra-national scales, while, at the local scale, classification normally tends to be based on practitioner judgement-stakeholders may play an important part in the characterization process, at the latter scale.

Finally, the "cultural" emerges as a landscape dimension spanning all levels of measurement of our 2-variable scheme, i.e., from field, farm and settlement patterns, historical development, and heritage (qualitative, but objective factors) to more esoteric, experiential, 
and stakeholder input (qualitative, subjective factors). In addition, the "visual" factor similarly spans a broad range in our 2-variable scheme, i.e., MEDSCAPES LCA classifications [39] range from objective reporting of quantified landscape features to the recording of "the human perception of prominent visual characteristics and/or locally distinctive features" [40].

\section{Concluding Thoughts}

Although subjective and qualitative methods and tools remain steadily integral to LCA approaches, our meta-analysis findings point to the preponderance of the quantitative over the qualitative, and of the objective over the subjective, with fairly well distributed neutral-in terms of balance between the 2 poles of these 2 variables-cases of reference to LCA methods and tools. Not surprisingly, the meta-analysis also shows the connection between quantitative and objective aspects/approaches in the sources studied, as well as progressively more inclusive approaches to LCA, such as an increasing involvement of the public and relevant stakeholders in LCA processes. The latter is in line with ELC's advocating for public participation in landscape assessment processes and the formulation of landscape quality objectives [1]. The findings of our meta-analysis generally concur with and support other relevant research, i.e., "the use of focus groups has mushroomed in applied landscape research transferred into policy outcomes", although cautioning that such qualitative methodologies should not be used in isolation from quantitative ones [29].

Despite the fact that this was not an intention of our meta-analysis, the literature search for the creation of our database generally reaffirmed, once again, that landscape character assessment is a useful tool for a variety of different sectors related to landscape planning, policy management, regarding both environmental and societal initiatives. In this context, the need for more advanced and finely tuned, but also more user-friendly, objective and quantitative tools remains. However, for these such tools to be effective and efficient, they ought to be employed by experts trained in all of the above methods and tools (both objective/quantitative and subjective/qualitative), so that landscape assessment and analysis is not subject to strictly standardized forms of mapping processes. As summarized by Swanwick et al. [12]:

[LCA] can be a powerful tool to aid the planning, design and management of landscapes. Use of GIS and methods of computer analysis should not, however, be at the expense of proper consideration of the perceptual and aesthetic factors which influence character. Nor should it distract from the need to engage stakeholders in meaningful ways. Judgements based on landscape character need to take account of several factors. Most importantly it is vital to decide who is going to be involved in making the judgements. For practical reasons some assessments may still rely mainly on judgements made by professionals. It is nevertheless important to involve stakeholders in this part of the process if the judgements are to command wide support and are to be as fully informed as possible [10].

One excellent example is the living landscapes approach [49], a strong case for the development and adoption of a commonly agreed-upon system of landscape assessment, structured in such a way that it is capable of accommodating the wide range of landscapes across Europe. This approach may serve as a complementary tool to the process of local spatial planning of small places and urban settlements. Such a system needs to be hierarchical, thus enabling users to select the appropriate level of detail and mapping scale for different applications and to incorporate data from a range of sources and formats. It should, ideally, provide a suitable spatial framework for the incorporation of additional data (i.e., ranging from evaluating indices of ecological quality and landscape sensitivity/capacity to enrichment with cultural information relating to public perception/appreciation/understanding of landscape character and evolution) [49].

Regarding the delimitations of our study, although scale is significant in the process of LCA implementation, we did not include it as an analytical variable in our study, since we only analyzed those sources available to us through our literature review, which revealed very different perspectives to scale. Furthermore, as far as delimitations are 
concerned, there exists a strong possibility of the following: Having inadvertently missed some related articles and especially those before 2000, not uploaded on research web pages; the judgement of selecting and grouping the sources was based on experts' subjective decision-making rather than objective/quantitative tools; and many sources were not published in English, and as such could not be incorporated in our literature review.

Despite an apparent evolution and refinement in recent scientific contributions, the potential for further future research in this area of study is very significant, i.e., in terms of the inclusion of more variables in such meta-analyses. Specifically, our database could be further expanded in scope and in size, to include all possible bibliographical sources referencing the LCA method, in all languages. Besides a more exhaustive list of references, a more stringent, analytical, and/or quantitative approach to the assessment of the interplay between our two variables may be effectuated, by larger researcher teams representing variable disciplinary orientations and research perspectives to LCA analysis and implementation. A more coherent, comprehensive, and agreed-upon LCA methodology and terminology, as well as appropriate LCA training among pertinent professionals, researchers, and decision-makers, are yet to be instigated, while policy makers tread uncertainly in this veritable minefield of operations [39,82].

We would like to conclude by emphasizing the inevitable obsolescence of any strict landscape classification scheme, due to the fluid, ever-changeable nature of landscape itself: Every landscape is both a tangible and intangible object, both permanent and ephemeral, existing simultaneously in human "realities" and aspirations [39]. Nonetheless, the challenge of integrating successfully and appropriately the two poles of our 2-variable scheme remains. Encouragingly, though, it seems that this task is increasingly and more and more creatively addressed and assumed by landscape-related scientists and practitioners, as this overview of LCA versions has aspired to show.

Author Contributions: Conceptualization, T.S.T.; methodology, T.S.T., A.G., D.K.; software, D.K.; validation, T.S.T., D.K.; formal analysis, T.S.T., A.G., D.K.; investigation, T.S.T., A.G., D.K.; data curation, D.K.; writing — original draft preparation, T.S.T., A.G., D.K.; writing—review and editing, T.S.T., A.G.; visualization, D.K.; supervision, T.S.T. All authors have read and agreed to the published version of the manuscript.

Funding: This research received no external funding.

Institutional Review Board Statement: Not applicable.

Informed Consent Statement: Not applicable.

Data Availability Statement: All data presented in this study are available in this article.

Conflicts of Interest: The authors declare no conflict of interest.

\section{References}

1. Council of Europe. European Landscape Convention; European Treaty Series-No 176; Council of Europe: Florence, Italy, 2000; pp. 1-7.

2. Antrop, M.; Sevenant, M.; Tagliaferro, C.; Van Eeetvelde, V.; Witlox, F. Setting the framework for valuing the multifunctional landscape and its multiple perceptions. In The Economic Value of Landscapes; Heijman, W., Van der Heide, M., Eds.; Routledge: London, UK, 2013.

3. Plieninger, T.; Hui, C.; Gaertner, M.; Huntsinger, L. The impact of land abandonment on species richness and abundance in the Mediterranean Basin: A meta-analysis. PLoS ONE 2014, 9, e98355. [CrossRef] [PubMed]

4. Jorgensen, A. What is happening to landscape? Landsc. Res. 2017, 42, 1-5. [CrossRef]

5. Vogiatzakis, I.N. Mediterranean experience and practice in Landscape Character Assessment. Ecol. Mediterr. 2011, 37, 17-31. [CrossRef]

6. Kolejka, J.; Lipský, Z. Landscape mapping and typology in the Czech Republic. Klasyf. Kraj. Teor. I Prakt. Probl. Ekol. Kraj. 2008, $X X, 67-78$.

7. Pinto-Correia, T.; Cancela D'abreu, A.; Oliveira, R. Landscape Units in Portugal and the Development and Application of Landscape Indicators. In Proceedings of the NIJOS/OECD Expert Meeting on Agricultural Landscape Indicators, Oslo, Norway, 7-9 October 2002; pp. 7-9. 
8. Simensena, T.; Halvorsena, R.; Erikstada, L. Methods for landscape characterization and mapping: A systematic review. Land Use Policy 2018, 75, 557-569. [CrossRef]

9. Terkenli, T.S.; Daras, T.; Maria, E.-A. Landscape Notions among Greek Engineering Students: Exploring Landscape Perceptions, Knowledge and Participation. Land 2019, 8, 83. [CrossRef]

10. Swanwick, C. Landscape Character Assessment Guidance for England and Scotland; The Countryside Agency and Scottish Natural Heritage: Gloucestershire, UK, 2002.

11. Groom, G.; Wascher, D.; Potschin, M.; Haines-Young, R. Landscape character assessments and fellow travelers across Europe: A review. In Landscape Ecology in the Mediterranean: Inside and Outside Approaches, 3rd ed.; IALE: Darwin, Australia, 2003; pp. 227-231.

12. Swanwick, C.; Cole, 1.; Diacono, M. Interim Landscape Character Assessment Guidance; The Countryside Agency and Scottish Natural Heritage: England, UK, 2002.

13. Griffiths, G.H.; Porter, J.; Simmons, E.; Warnock, S. The Living Landscapes Project: Landscape Character and Biodiversity; English Nature Report No 475; Natural England: Worcester, UK, 2004.

14. Blasi, C.; Carranza, M.L.; Frondoni, R.; Rosati, L. Ecosystem classification and mapping: A proposal for the Italian landscapes. Appl. Veg. Sci. 2000, 3, 233-242.

15. Marušič, J.; Jančič, M. Regional Distribution of Landscape Types in Slovenia: Methodological Bases; Ministry of Environment and Physical Planning: Ljubljana, Slovenia, 1998.

16. Gustafson, E.J. Quantifying landscape spatial pattern: What is the state of the art? Ecosystems 1998, 1, 143-156.

17. Mc Garigal, K.; Cushman, S.A. Comparative evaluation of experimental approaches to the study of habitat fragmentation effects. Ecol. Appl. 2002, 12, 335-345.

18. O'Neil, R.V.; Milne, B.T.; Turner, M.G.; Gardner, R.H. Resource utilization scale and landscape pattern. Landsc. Ecol. 1988, 2, 63-69.

19. Tveit, M.S.; Ode, S.A.; Fry, G. Key concepts in a framework for analyzing visual landscape character. Landsc. Res. 2006, 31, 229-255. [CrossRef]

20. Ode, S.A.; Tveit, M.S.; Fry, G. Capturing Landscape Visual Character Using Indicators: Touching Base with Landscape Aesthetic Theory. Landsc. Res. 2008, 33, 89-117. [CrossRef]

21. Lothian, A. Landscape and the philosophy of aesthetics: Is landscape quality inherent in the landscape or in the eye of the beholder? Landsc. Urban Plan. 1999, 44, 177-198. [CrossRef]

22. Zube, E.H.; Pitt, D.G.; Evans, G.W. A lifespan developmental study of landscape assessment. J. Environ. Psychol. 1983, 3, 115-128. [CrossRef]

23. Gkoltsiou, A.; Terkenli, T.S. An interdisciplinary analysis of tourist landscape structure. Tour. J. 2012, 7, 145-164.

24. Turner, M.G.; Carpenter, S.R. At last: A journal devoted to ecosystems. Ecosystems 1998, 1, 11-15.

25. Gkoltsiou, A.; Terkenli, S.T.; Koukoulas, S. Landscape Indicators for the evaluation of tourist landscape structure. Int. J. Sustain. Dev. World Ecol. 2013, 20, 461-475. [CrossRef]

26. Hampshire County Council. Advise to Communities on Undertaking a Local Landscape Character Assessment. Assessing and Maintaining Local Distinctiveness; The Strategic Environmental Delivery Group: Hampshire, UK, 2012.

27. Penning-Rowsell, E.C.; Hardy, D.I. Landscape evaluation and planning policy: A comparative survey in the Wye Valley Area of Outstanding Natural Beauty. Reg. Stud. 1973, 16, 97-112.

28. House, M.; Fordham, M. Public perception of River Corridors and Attitudes towards River Works. Landsc. Res. 1997, 22, 25-44. [CrossRef]

29. Dunn, M.C. Landscape with photographs: Testing the preference approach to landscape evaluation. J. Environ. Manag. 1976, 4, $15-26$.

30. Shafer, E.L.; Brush, R.O. How to measure preferences for photographs of natural landscapes. Landsc. Plan. 1977, 4, $237-256$.

31. Byrne, S.M. Perception of the landscape in the Lands End Peninsula. Landsc. Res. 1979, 5, 21-24. [CrossRef]

32. Rieser, R. Urban Spatial Images: An Appraisal of the Choice of Respondents and Measurement Situation; London School of Economics: London, UK, 1972.

33. Bullen, J.M.; Jones, E.M.; Scott, A.J. LANDMAP Pilot: Public Perception of Landscape; Unpublished Report to Countryside Council for Wales; Countryside Council for Wales: Bangor, UK, 1998.

34. Bullen, J.M.; Jones, E.M.; Scott, A.J. LANDMAP: Public Perception of the Gwynedd Landscape; Unpublished Report to Gwynedd County Council; Gwynedd County Council: Gwynedd, UK, 1998.

35. Kingston, R.; Carver, S.; Evans, A.; Turton, I. Virtual Decision Making in Spatial Planning: Web-based Geographical Information Systems for Public Participation in Environmental Decision Making. In Proceedings of the International Conference on Public Participation and Information Technology, Lisbon, Portugal, 20-22 October 1999.

36. Tress, B.; Tress, G. Scenarios for the multifunctional use of landscapes in Denmark. In Proceedings of the Centre for Landscape Research, Roskilde, Denmark, 18-21 October 2000. Available online: http:/ /www.tress.cc/scenario.html (accessed on 20 September 2000).

37. Yorkshire Dales National Park. Landscapes for Tomorrow; Yorkshire Dales National Park: Grassington, UK, 1992.

38. Nogué, J.; Sala, P. Prototype Landscape Catalogue Conceptual, Methodological, and Procedural Bases for the Preparation of the Catalan Landscape Catalogues; Observatory de Paisatge: Olot/Barcelona, Spain, 2006; pp. 1-31.

39. Scott, A. Assessing Public Perception of Landscape: From Practice to Policy. J. Environ. Policy Plan. 2003, 5, 123-144. [CrossRef] 
40. Eurostat; D.G. Agriculture; DG Environment; Joint Research Center; European Environment Agency. Towards Agri-Environmental Indicators; EEA: Copenhagen, Denmark, 2001.

41. Martin, J.; Farmer, A. Landscape Character Assessment in Ireland: Baseline Audit and Evaluation; The Heritage Council: Dublin, UK, 2007; pp. 1-66. ISBN 978-1-906304-01-0.

42. The Countryside Agency. Landscape Character Assessment; Scottish Natural Heritage: Edinburgh, UK, 2002; pp. 1-16.

43. Tudor, C. An Approach to Landscape Character Assessment; Natural England: York, UK, 2014; pp. 1-57.

44. ESPON. Liveable Landscapes: A Key Value for Sustainable Territorial Development; ESPON Monitoring Committee: Luxembourg, 2015.

45. Wascher, D.M. European Landscape Character Areas-Typologies, Cartography, and Indicators for the Assessment of Sustainable Landscapes; Landscape Europe, ELCAI: Wageningen, The Netherlands, 2005; p. i-150.

46. King, G. Cotswold Water Park Integrated Landscape Character Assessment; Final Report; LDA DESIGN: London, UK, 2009; pp. 9-12. [CrossRef]

47. Abu-Jaber, N.; Abunnasr, Y.; Yahya, A.; Boulad, N.; Christou, O.; Dimitropoulos, G.; Dimopoulos, T.; Gkoltsiou, K.; Khreis, N.; Manolaki, P.; et al. Travelling in the eastern Mediterranean with landscape character assessment. In Proceedings of the Third International Conference on Remote Sensing and Geoinformation of the Environment, Proc. of SPIE, Pafos, Cyprus, 16-19 March 2015; Volume 9535.

48. Tsilimigkas G.; Gourgiotis A. Landscape management in regional planning studies. In Methods of Analysis and Greek Landscape Management; Aeihoros: Thessaly, Greece, 2014; Volume 19, pp. 24-37. (In Greek)

49. Warnock, S.; Griffiths, G. Landscape Characterization: The living landscapes approach in the UK. Landsc. Res. 2014, 40, 261-278. [CrossRef]

50. Uzun, O.F.; Dilek, G.; Çetinkaya, F.; Erduran, S.; Açiksöz, S. National and Regional Landscape Classification and Mapping of Turkey: Konya Closed Basin, SuğLa Lake and its Surrounding Area. Int. J. Phys. Sci. 2011, 6, 550-565.

51. Mediterranean Institute for Nature and Anthropos. Best Practice Methodology for Landscape Character Assessment; Final Report for Work Package 4; MEDSCAPES Project: Athina, Greece, 2014-2015.

52. Brunetta, G.; Voghera, A. Evaluating Landscape for Shared Values: Tools, Principles, and Methods. Landsc. Res. 2008, 33, 71-87. [CrossRef]

53. Trop, T. From knowledge to action: Bridging the gaps toward effective incorporation of Landscape Character Assessment approach in land-use planning and management in Israel. Land Use Policy 2017, 61, 220-230. [CrossRef]

54. Herlin, S.I. Exploring the national contexts and cultural ideas that preceded the Landscape Character Assessment method in England. Landsc. Res. 2016, 41, 175-185. [CrossRef]

55. Fairclough, G.; Herring, P. Lens, mirror, window: Interactions between historic landscape characterization and landscape character assessment. Landsc. Res. 2016, 41, 186-198. [CrossRef]

56. Stenseke, M. Integrated landscape management and the complicating issue of temporality. Landsc. Res. 2016, 41, 199-211. [CrossRef]

57. Dalglish, C.; Leslie, A. A question of what matters: Landscape characterization as a process of situated, problem-orientated public discourse. Landsc. Res. 2016, 41, 212-226. [CrossRef]

58. Primdahl, J.; Kristensen, L.S. Landscape strategy making and landscape characterization—experiences from Danish experimental planning processes. Landsc. Res. 2016, 41, 227-238. [CrossRef]

59. Butler, A. Dynamics of integrating landscape values in landscape character assessment: The hidden dominance of the objective outsider. Landsc. Res. 2016, 41, 239-252. [CrossRef]

60. Olwig, K.R. Virtual enclosure, ecosystem services, landscape's character and the 'rewilding' of the commons: The 'Lake District' case. Landsc. Res. 2016, 41, 253-264. [CrossRef]

61. Van Eetvelde, V.; Antrop, M. A stepwise multi-scaled landscape typology and characterization for trans-regional integration, applied on the federal state of Belgium. Landsc. Urban Plan. 2009, 91, 160-170. [CrossRef]

62. Aretano, R.; Petrosillo, I.; Zaccarelli, N.; Semeraro, T.; Zurlini, G. People perception of landscape change effects on ecosystem services in small Mediterranean islands: A combination of subjective and objective assessments. Landsc. Urban Plan. 2013, 112, 63-73. [CrossRef]

63. Guo, L.; Zhang, B. Identification of landscape character types for trans-regional integration in the Wuling Mountain multi-ethnic area of southwest China. Landsc. Urban Plan. 2017, 162, 25-35. [CrossRef]

64. Jellema, A.; Stobbelaar, D.-J.; Groot, J.C.J.; Rossing, W.A.H. Landscape character assessment using region growing techniques in geographical information systems. J. Environ. Manag. 2009, 90, S161-S174. [CrossRef]

65. Bellen, L.; Ortega, E.; Otero, I.; Arce, R.M. Landscape character assessment with GIS using map-based indicators and photographs in the relationship between landscape and roads. J. Environ. Manag. 2016, 180, 324-334. [CrossRef]

66. Mahan, A.; Mansouri, S.A. Developing a Landscape Assessment Model (A review study of current methods and approaches to landscape assessment). Sci. J. Nazar. Res. Cent. Art Archit. Urban. 2017, 14, 31-40. 
67. Alfred, O. Landscape: Identifying and assessing landscape through historic landscape characterization. In Effects of Afforestation on Ecosystems, Landscape and Rural Development, Proceedings of the AFFORNORD Conference, Reykholt, Iceland, 18-22 June 2005; pp. 227-234. Available online: https://d1wqtxts1xzle7.cloudfront.net/1421165/Aldred_2007 .pdf?response-content-disposition=inline\%3B+filename\%3DIdentify-ing_and_assessing_landscape_thro.pdf\&Expires=16 10103657\&Signature=PM2i6gHRkax \{\}f6 \{\}SesMsqFCvvItI0CV9K5WzfzId87qiIYVP4PY1Ip \{\}L0hQ \{\}bCrWlML9fyTgQz8 ASEHEJEUKsnfkRUVjBaInDJmeqXxTQVIpXfds6iTiiWeD-pF0V4cbSP5nA5VrmIuF7T-ib2yztFMNzLailpsFDUU3AaSY1 DXT8OyiMsaK47NXiYTbPhZEuBRv3RlxOPElQI40Y7yXMDdQFTjPN6PFT5MJwGTK \{\}XzZCFwQMs8nWOC8J12L0aq9 0pycdeid3NaqMQfPyUKqwahus7qiuvipeemPJicjv7t93mg2F3 \{\}cFJzjJiLdGoz8-2nCETU1bdxOFd6Za7MYTQ_\&Key-Pair-Id= APKAJLOHF5GGSLRBV4ZA (accessed on 20 September 2000).

68. Butler, A.; Berglund, U. Landscape Character Assessment as an Approach to Understanding Public Interests within the European Landscape Convention. Landsc. Res. 2012, 39, 219-236. [CrossRef]

69. Caspersen, O.H. Public participation in strengthening cultural heritage: The role of landscape character assessment in Denmark. Geogr. Tidsskr. Dan. J. Geogr. 2009, 109, 33-45. [CrossRef]

70. Fairclough, G.J. Steps towards the integrated management of a changing landscape: Historic Landscape Characterization in England, in Swensen. Cult. Herit. Urban Fringe Nannetsad Workshop Rep. 2002, 29-39.

71. Fairclough, G.; Herlin, I.S.; Swanwick, C. Landscape character approaches in global, disciplinary and policy context: An introduction. In Routledge Handbook of Landscape Character Assessment; Routledge: London, UK, 2018; pp. 3-20.

72. Swanwick, C.; Fairclough, G. Landscape character: Experience from Britain. In Routledge Handbook of Landscape Character Assessment; Routledge: London, UK, 2018; pp. 21-36.

73. Herlin, I.S.; Nord, J.; Qviström, M. Landscape Characterization in Sweden. In Routledge Handbook of Landscape Character Assessment: Current Approaches to Characterization and Assessment; Routledge: London, UK, 2018; p. 53.

74. Atik, M.; Karadeniz, N. New approaches for new regions: Turkey. In Routledge Handbook of Landscape Character Assessment; Routledge: London, UK, 2018; pp. 69-79.

75. Warnock, S.; Enotiades, P.; Griffiths, G. Developing a landscape character map of Cyprus. In Routledge Handbook of Landscape Character Assessment; Routledge: London, UK, 2018; pp. 80-89.

76. Andlar, G.; Aničić, B. Multi-method approaches to cultural landscape assessment in Croatia. In Routledge Handbook of Landscape Character Assessment: Current Approaches to Characterization and Assessment; Routledge: London, UK, 2017.

77. Loupa-Ramos, I.; Pinto-Correia, T. Landscape Character Assessment across Scales. In Routledge Handbook of Landscape Character Assessment: Current Approaches to Characterization and Assessment; Routledge: London, UK, 2018; p. 88.

78. Käyhkö, N.; Fagerholm, N.; Khamis, M.; Hamdan, S.I.; Juma, M. The collaborative, Participatory Process of Landscape Character Mapping for Land and Forest Planning in Zanzibar, Tanzania. In Routledge Handbook of Landscape Character Assessment; Routledge: London, UK, 2018; pp. 118-127.

79. Palmer, J.F.; Smardon, R.C. Approaches related to landscape character assessment. In Routledge Handbook of Landscape Character Assessment: Current Approaches to Characterization and Assessment; Routledge: London, UK, 2018; p. 131.

80. R Core Team. R: A Language and Environment for Statistical Computing; R Foundation for Statistical Computing: Vienna, Austria, 2020.

81. Olwig, K.R.; Dalglish, C.; Fairclough, G.; Herring, P. Introduction to a special issue: The future of landscape characterization, and the future character of landscape-between space, time, history, place and nature. Landsc. Res. 2016, 41, 169-174. [CrossRef]

82. Burgess, J.; Harrison, C.; Lumb, M. Exploring environmental values through medium of small groups. Environ. Plan. 1988, 20, 309-326. [CrossRef] 